\title{
Assessing the Theoretical Prospects of Bioethanol Production as a Biofuel from Agricultural Residues in Bangladesh: A Review
}

\author{
Monirul Islam Miskat ${ }^{1,+} \oplus$, Ashfaq Ahmed ${ }^{2,3,+}{ }^{\circ}$, Hemal Chowdhury ${ }^{4}\left(\mathbb{D}\right.$, Tamal Chowdhury ${ }^{1}$, \\ Piyal Chowdhury ${ }^{5}$, Sadiq M. Sait ${ }^{6}{ }^{\circ}$ and Young-Kwon Park ${ }^{2, *}$ \\ 1 Department of Electrical \& Electronic Engineering, Chittagong University of Engineering \& Technology, \\ Kaptai Highway, Chattogram 4349, Bangladesh; monirulislammiskat@gmail.com (M.I.M.); \\ tamalshanto@gmail.com (T.C.) \\ 2 School of Environmental Engineering, University of Seoul, Seoul 02504, Korea; ashfaqengr97@gmail.com \\ 3 COMSATS University Islamabad, Lahore Campus, Off Defence Road, Raiwind Road, Lahore 54000, Pakistan \\ 4 Department of Mechanical Engineering, Chittagong University of Engineering \& Technology, Kaptai \\ Highway, Raozan, Chattogram 4349, Bangladesh; hemalchowdhuryme13@gmail.com \\ 5 Chattogram Collegiate School and College, Chattogram 4200, Bangladesh; cyborgpiyal2@gmail.com \\ 6 CCITR-RI, King Fahd University of Petroleum \& Minerals, Dhahran 31261, Saudi Arabia; \\ sadiq@kfupm.edu.sa \\ * Correspondence: catalica@uos.ac.kr \\ + Co-first authors.
}

Received: 2 September 2020; Accepted: 14 October 2020; Published: 16 October 2020

\begin{abstract}
This study reviewed the aspects of the production of bioethanol from the agricultural residues available in Bangladesh. The crop residues such as rice, wheat, sugarcane, corn, cotton, jute, and sugarcane have great potential for energy generation in a sustainable and eco-friendly way in Bangladesh, as these residues are available in large quantities. Bioethanol is an alternative fuel to gasoline that provides comparable performance results. Bioethanol from these residues can be used for transportation purposes, as it does not require any major modifications to the spark-ignition engine configuration when using E5 blend (5\% Ethanol mixed with 95\% of the gasoline). In Bangladesh, approximately $65.36 \mathrm{Mt}$ of agricultural residues are available from the major crops, from which $32 \mathrm{Mt}$ bioethanol can be generated. This study is expected to provide useful concise data with regards to the beneficial utilization of agricultural residues for bioethanol production in Bangladesh.
\end{abstract}

Keywords: bioethanol; agricultural residues; bioenergy; Bangladesh

\section{Introduction}

The demand for energy has increased significantly and is expected to increase further with the increase in urbanization, commercial activities, and population of the world. In previous decades, a significant portion of the demand for energy was met by burning the conventional fossil fuel resources [1-3]. Petroleum derivatives, being nonrenewable fuels, which produce significant amounts of greenhouse gases in the environment causing severe environmental pollution, are predicted to deplete sooner rather than later [4,5]. The storage of oil is expected to be depleted by 2052 (at the recent utilization pace of 4 billion tons/year), and coal stores will last until only 2088 [6,7]. For these reasons, more consideration is now being given to renewable sources. Bioenergy is the energy derived from renewable sources, such as agricultural waste, animal manure, municipal waste, and others. Biomass energy is renewable and sustainable, because it does not hamper the environment [8]. Biomass can be converted to fuels using a range of methods and technologies. There are two major routes for biomass 
conversion, one is the biochemical route (anaerobic digestion, aerobic digestion, and fermentation) and another is thermochemical route (pyrolysis, gasification, liquefaction, and combustion). The United States is seeking alternatives to make biofuels from inexhaustible biomass and has decided to produce 90 billion gallons (341 billion liters) of biofuels every year [9]. Different feedstocks have been employed and investigated for the bioethanol production. Approximately 7.3 billion gallons ( 27.6 billion liters) and 15.25 billion gallons ( $\sim 57.7$ billion liters) of ethanol are produced annually by Brazil and the United States, respectively, whereas other countries, such as China and Canada, produce $\sim 845$ million gallons ( $\sim 3.2$ billion liters) and $\sim 436$ million gallons annually [10].

Corn, wheat, sugarcane and other resources have been used for bioenergy conversion, and they have different percentages of cellulose, hemicellulose, and lignin material. Considering cellulose (wt $\%$ ) in lignocellulose wastes, corn stalks have 37\%, wheat straw has $32.9 \%$, and sugarcane bagasse has the highest percentage at $40.0 \%$. Regarding hemicellulose (wt $\%$ ), cornstalks, wheat straw, and sugarcane bagasse have a percentage of $16.8 \%, 24 \%$, and $27 \%$, respectively [11]. The percentage of different elements like volatile matter, fixed carbon, ash content, nitrogen, hydrogen, oxygen, high heating value, and sulphur found in agricultural residues can be obtained by proximate and ultimate analysis. It is found that agricultural residue has the highest percentage of volatile matter in a range of $61.2-76.05 \%, 14-24 \%$ fixed carbon content, 38-50\% carbon, and 30-43\% oxygen. Agricultural residues have a higher heating value in the range of $14.66-20.58 \%(\mathrm{MJ} / \mathrm{kg})[12,13]$. The addition of bioethanol into other fuels is a widely practiced method to produce renewable energy. The addition of bioethanol into other fuels changes the physicochemical properties of the fuel blend. Likewise, E5 is a fuel blend of 5\% ethanol and 95\% of the gasoline. Physiochemical properties of bioethanol and E5 are shown in Table 1 [14]

Table 1. Physicochemical characteristics of bioethanol and E5 [14].

\begin{tabular}{ccc}
\hline Fuel Property & E5 & Bioethanol \\
\hline Density at $15^{\circ} \mathrm{C}$ & $834.3 \mathrm{~kg} / \mathrm{m}^{3}$ & $790.0 \mathrm{~kg} / \mathrm{m}^{3}$ \\
Kinematic viscosity at $40{ }^{\circ} \mathrm{C}$ & $2.53 \mathrm{~mm}^{2} / \mathrm{s}$ & $1.130 \mathrm{~mm}^{2} / \mathrm{s}$ \\
Cetane number & - & 5.8 \\
Octane number & - & 110 \\
Flashpoint & $24^{\circ} \mathrm{C}$ & $13^{\circ} \mathrm{C}$ \\
Calorific value & $43.6318 \mathrm{MJ} / \mathrm{kg}$ & $25.22,26.70 \mathrm{MJ} / \mathrm{kg}$ \\
Water content & $100 \mathrm{mg} \mathrm{kg}^{-1}$ & $2024 \mathrm{mg} \mathrm{kg}$ \\
\hline
\end{tabular}

In Bangladesh, a large number of agricultural residues are generated every year. These wastes are used for traditional cooking purposes, resulting in the inefficient utilization of these resources, as there is no policy at present available to transform these wastes into renewable fuels such as bioethanol. The majority of these biomass resources are used in rural areas, mainly for cooking and heating purposes. Approximately $60 \%$ of the total energy demand of the people in Bangladesh is met by the biomass resources. As a result, much of this energy is wasted. The consumption of different biomass resources per household throughout Bangladesh is given in Table 2. Commercial utilization of biomass is relatively low, but currently different government and private organizations are investing in expanding the biomass-based market in Bangladesh. Two power plants of $1 \mathrm{MW}$ and $300 \mathrm{KW}$ are set up by the Government of Bangladesh and IDCOL. Various studies have been reported in literature on the biomass availability and generation of power from biomass in Bangladesh. A study by Hossen et al. reported that the utilization of one third of biomass in Bangladesh is capable of providing the overall energy demand of the country [15]. Uddin et al. explored the potential of the biomass in Bangladesh by considering the agricultural residue, forest residue, municipal and industrial solid wastes, animal manure, and human excreta. This study also revealed that the biomass is a sustainable resource for power generation in Bangladesh [16]. A study was led by Salam et al. to explore the potential of hydrogen production in Bangladesh from biomass, which also analyzed various hydrogen production parameters such as pressure, biomass and reagent ratios, equivalence ratios, bed material, gasifying 
agents, and catalysts' effect and temperature [17]. All these studies have reported the overall satisfying potential of biomass resources to produce renewable energy in Bangladesh in a general sense. To gain a deep understanding and policy development insights, it is crucial to assess the potentiality of each type of biofuel production by employing a specific processing technology and feedstock such as bioethanol production from agricultural residues in Bangladesh. However, to date there has been no such study to explore the potential of bioethanol production from agricultural residues in Bangladesh. Therefore, this study examined the existing research gap to highlight the potential of these wastes to generate bioethanol. In addition to the production of bioethanol, appropriate blending is also highly recommended, which will help policymakers consider bioethanol as a fuel in the automobile sector.

Table 2. Per household different biomass resources consumption throughout Bangladesh [18].

\begin{tabular}{ccccc}
\hline Biomass Resources & Wholly Use & \multicolumn{3}{c}{ Boiler } \\
\hline & & Cuisine & Streaming Rice & Others \\
Sawdust $(\mathrm{kg})$ & 8 & 8 & 0.02 & 0.02 \\
Firewood $(\mathrm{kg})$ & 1106 & 1065 & 29 & 93 \\
Tree leaves $(\mathrm{kg})$ & 502 & 471 & 30 & 0.9 \\
Crop residue $(\mathrm{kg})$ & 708 & 539 & 164 & 2.7 \\
Dung stick $(\mathrm{kg})$ & 524 & 504 & 16 & 4.2 \\
\hline
\end{tabular}

\section{Transformation of Agro-Waste into Bioethanol}

The production of bioethanol from the cellulosic ingredients of agroforestry waste can be divided into several stages such as milling, enzymatic hydrolysis, pretreatment, fermentation, and rectification [19]. As for each of these operations, enzymes are needed, the cost of the entire system becomes higher. The following three crucial steps are considered to be the main factors limiting the rates and influencing the process efficiency of agroforestry conversions: pretreatment, fermentation, and enzymatic hydrolysis. Pretreatment is generally done to isolate lignin and hemicellulose from cellulose. Several types of pretreatment methods such as physicochemical (steam pretreatment, hydrothermolysis, and wet oxidation), physical (milling and grinding), chemical (organic solvents, oxidizing agents, dilute acid, and alkali), electrical, biological, and a combination of these are done. Then, this cellulose is hydrolyzed by the enzymes to obtain fermentable sugars. After this step, fermentation is done to transform the sugars into bioethanol. Finally, after converting sugars into bioethanol, distillation is done to purify it. Figure 1 presents the various steps involved in the production of bioethanol from various biomass feedstocks.

Normally, the pretreatment consists of the following steps: chemical methods (acids, oxidizing agents mixture with bases, ozonolysis, organic solvents, and ionic liquids) [20,21]; physical methods, e.g., to extract lignin materials, pressure as well as temperature are varied accordingly (extrusion, irradiation, etc.) [22,23]; physiochemical processes (explosion via steam, ARP, AFE, etc.) [24,25]; and biological methods, such as white rot as well as marine fungi [26,27]. Table 3 shows the advantages and disadvantages of various pretreatment methods for processing lignocellulose materials. 


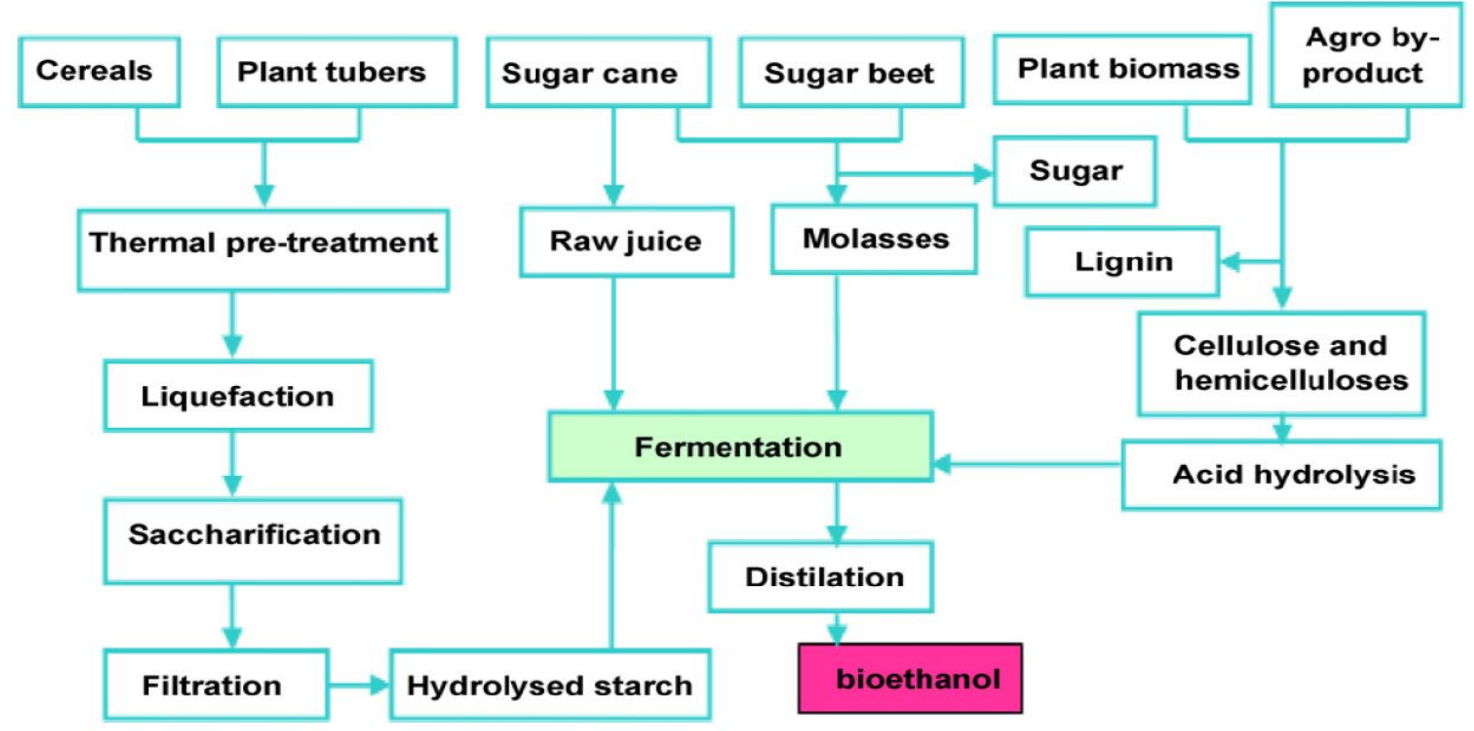

Figure 1. Different stages of bioethanol production technology, reprinted with permission from Najfi et al. [28].

Table 3. Pros and cons of various pretreatment methods for processing lignocellulose materials [29].

\begin{tabular}{|c|c|c|c|}
\hline Pretreatment & & Advantages & Disadvantages \\
\hline \multirow[t]{8}{*}{ Chemical } & Acids & $\begin{array}{l}\text { High amount of glucose } \\
\text { supply }\end{array}$ & $\begin{array}{l}\text { Financial cost associated with } \\
\text { acids and recovery }\end{array}$ \\
\hline & $\begin{array}{l}\text { Combination of bases } \\
\text { as well as oxidizing } \\
\text { agents }\end{array}$ & Ambient temperatures & $\begin{array}{l}\text { Generation of degradation } \\
\text { products }\end{array}$ \\
\hline & $\begin{array}{l}\text { Solvents which are } \\
\text { organic in nature }\end{array}$ & $\begin{array}{l}\text { Responsible for not only lignin } \\
\text { but also hemicellulose } \\
\text { hydrolysis }\end{array}$ & Expensive \\
\hline & Ozonolysis & High delignification efficiency & $\begin{array}{c}\text { Draining as well as recycling of } \\
\text { solvents }\end{array}$ \\
\hline & & $\begin{array}{l}\text { Low generation of } \\
\text { degradation products }\end{array}$ & Large amounts of ozone needed. \\
\hline & & High glucose yield & \\
\hline & Ionic liquids & $\begin{array}{l}\text { Low formation of toxic } \\
\text { inhibitors }\end{array}$ & Costly solvents \\
\hline & & $\begin{array}{l}\text { Low generation of } \\
\text { degradation products }\end{array}$ & $\begin{array}{c}\text { Draining as well as recycling of } \\
\text { solvents are necessary }\end{array}$ \\
\hline \multirow[t]{6}{*}{ Physical } & $\begin{array}{l}\text { Irradiation or } \\
\text { microwave }\end{array}$ & Faster heat transfer & $\begin{array}{l}\text { Poor radiation penetration in } \\
\text { products }\end{array}$ \\
\hline & & Shorter reaction times & \\
\hline & Milling & $\begin{array}{l}\text { Cellulose crystallinity is } \\
\text { decreased }\end{array}$ & Greater intake of energy \\
\hline & $\begin{array}{l}\text { Mechanical } \\
\text { comminution }\end{array}$ & $\begin{array}{l}\text { Cellulose crystallinity is } \\
\text { decreased }\end{array}$ & Greater consumption of energy \\
\hline & & $\begin{array}{l}\text { Causes reduction in the degree } \\
\text { of polymerization }\end{array}$ & \\
\hline & Extrusion & $\begin{array}{l}\text { Low formation of toxic } \\
\text { inhibitors }\end{array}$ & $\begin{array}{l}\text { Temperature regulation difficulties } \\
\text { associated with temperature } \\
\text { control, cooling capacity is not } \\
\text { flexible }\end{array}$ \\
\hline
\end{tabular}


Table 3. Cont.

\begin{tabular}{|c|c|c|c|}
\hline Pretreatment & & Advantages & Disadvantages \\
\hline & & $\begin{array}{l}\text { Generation of degradation } \\
\text { products is lower }\end{array}$ & Limited residence time \\
\hline \multirow[t]{4}{*}{ Biological } & & Low energy consumption & Low rate of hydrolysis \\
\hline & & Capital cost is less & \\
\hline & & $\begin{array}{l}\text { Chemicals are not required at } \\
\text { all }\end{array}$ & \\
\hline & & $\begin{array}{l}\text { Mild environmental } \\
\text { conditions }\end{array}$ & \\
\hline \multirow[t]{10}{*}{ Physicochemical } & Liquid hot water & Not catalyst requirement & Not developed at commercial scale \\
\hline & & Low-cost reactor construction & \\
\hline & Steam explosion & $\begin{array}{l}\text { Causes lignin transformation } \\
\text { and hemicelluloses } \\
\text { solubilization }\end{array}$ & Generation of toxic compounds \\
\hline & & Cost-effective & \\
\hline & $\mathrm{CO}_{2}$ explosion & $\begin{array}{l}\text { Increases accessible surface } \\
\text { area }\end{array}$ & Very high-pressure requirements \\
\hline & & Cost-effective & \\
\hline & $\begin{array}{l}\text { Ammonia fiber } \\
\text { explosion }\end{array}$ & $\begin{array}{l}\text { Enhance the surface areas } \\
\text { which can be accessed }\end{array}$ & $\begin{array}{l}\text { A high amount of } \mathrm{NH}_{3} \text { is needed, } \\
\text { so cost increases }\end{array}$ \\
\hline & & Inhibitors formation is lower & \\
\hline & $\begin{array}{c}\text { Soaking aqueous } \\
\text { ammonia }\end{array}$ & $\begin{array}{l}\text { Performed at a lower } \\
\text { temperature }\end{array}$ & Higher cost \\
\hline & & Low formation of inhibitors & \\
\hline
\end{tabular}

Some harmful inhibitors, especially the phenolic compounds (hydroxyl groups are attached with the main structure), derivatives of furan, along with weak acids are derived during the hydrolysis process of lignocellulosic biomass material. These toxic compounds need to be drawn out immediately via a detoxification process after chemical, physical, and physiochemical pretreatments [30]. The formation of inhibitors and corrosion is one of the major drawbacks of hydrolysis. In addition, biological pretreatment is more time consuming than other pretreatment processes, and there is a chance of degradation of the cellulose and hemicelluloses. On the other hand, these processes are eco-friendly, as they do not require additional methods for processing residual streams [31]. Enzymatic hydrolysis is the most common among all the hydrolysis methods to process lignocellulosic biomass materials. The acceptance of bioethanol as a high-quality energy source and for ecological sustainability is controversial, owing to the high investment costs of cellulase and hemicellulase enzymes [32]. According to Chovau et al. [33], regarding enzymatic hydrolysis, cellulase enzymes cost more than $\$ 26$ per $\mathrm{cm}^{3}$ of ethanol production. Although enzymatic hydrolysis, pretreatment, and fermentation are done in separate stages, enzymatic saccharification and fermentation can be integrated into a single stage instead of two different steps [34]. Currently, there is a drive to incorporate these steps to produce ethanol from lignocellulose. In the case of pretreatment via enzymatic hydrolysis (EH) and fermentation of biomass (FB), there are many problems to be solved, and various procedures have been suggested.

\subsection{Current Alternative Process Strategies for Bioethanol Production}

The most widely used technologies for bioethanol production from lignocellulosic biomass are the separate hydrolysis and fermentation (SHF), pre-saccharification followed by simultaneous saccharification and fermentation (PSSF), SSF, SSCF, and CBP [35,36]. During SHF, the treated lignocellulosic biomass is hydrolyzed to extract glucose via an enzymatic process. Sugar fermentation 
is then done to produce bioethanol. The fundamental convenience associated with this process is that these two stages are performed at the optimal temperature for not only cellulose enzymes but also yeast. However, one of the major drawbacks is the formation of glucose, which inhibits the cellulase enzymes [37]. In contrast, in the case of SHCF, the hydrolysis of hemicellulose, as well as cellulose, are done in different vessels. Altogether, pentose along with hexose are fermented [29]. The micro-organisms that can produce a high percentage of ethanol during the co-fermentation procedure of hexoses, as well as pentoses, are unavailable on a large scale [29]. Glucose production by utilizing enzymes and converting it to ethanol via the help of yeast decreases the rate of sugar accumulation in the overall process and averts cellulose inhibition caused by the sugars. Cellulase enzymes and yeast have different optimal working temperatures, which is one of the most crucial drawbacks. In recent years, some modified strains, for instance, Zymomonas mobilis [38], recombinant E. coli (KO11) [39], and Saccharomyces cerevisiae 1400 (pLNH33) [40], have been developed to ferment both pentose and hexose with the assistance of a microorganism. During the PSSF scheme, pretreated biomass is mixed with enzymes so that the saccharification process begins, and glucose begins to form after a few hours. The fermentative microorganism is then mixed with the solution to avoid the accumulation of glucose, and ethanol can be produced. The enzymes can perform a reaction at their optimal working temperature, and the viscosity in the system stays at a lower level during the first hours of the process [29]. To produce bioethanol as a single product, enzymes contribute up to $22 \%$ of the total cost, which is a large proportion [29].

The consolidated bioprocessing (CBP) is considered the most sustainable technology, because all the main steps can be performed in a reactor to produce ethanol. The financial expense and various curtailments associated with the conversion of lignocellulosic biomass to biofuel production is minimized to a greater extent via CBP [29]. Various microorganisms ranging from bacteria [29,41] to yeasts $[42,43]$ and fungi $[44,45]$ have been used in CBP systems, as they are the most reliable. The fundamental objective in CBP is to identify a microorganism (bacteria or yeasts) with the capability of (1) producing effective enzymes that will convert hemicellulose and cellulose into sugars, (2) eliminating lignin enzymatically to reduce chemical usage, (3) tolerating high inhibiting concentrations, and (4) transforming sugar to ethanol [46]. Table 4 lists the benefits as well as drawbacks in terms of the expenditure related to the enzymes, the time required by the equipment, and productivity of the processes described earlier.

Table 4. Benefit and blockage of various action preferences for bioethanol production [29,35,47].

\begin{tabular}{|c|c|c|}
\hline $\begin{array}{c}\text { Process } \\
\text { Alternatives }\end{array}$ & Advantages & Disadvantage \\
\hline SHF & $\begin{array}{l}\text { - At optimum temperature and } \\
\text { pressure not only enzymatic } \\
\text { hydrolysis, but also fermentation can } \\
\text { be done }\end{array}$ & $\begin{array}{l}\text { - } \quad \text { Cellulase activity is inhibited by } \\
\text { released glucose during enzymatic } \\
\text { hydrolysis process } \\
\text { - } \quad \text { Pretreatment step is required } \\
\text { - } \quad \text { Cellulase enzymes are costly }\end{array}$ \\
\hline СBP & $\begin{array}{l}\text { - Necessary enzymes, sugars along } \\
\text { with ethanol, are generated by } \\
\text { one microorganism } \\
\text { - } \quad \text { Pretreatment stage is optional }\end{array}$ & $\begin{array}{l}\text { - Conversion time is more than } \\
\text { other processes } \\
\text { - Lower productivity as well as } \\
\text { ethanol yield }\end{array}$ \\
\hline SHCF & $\begin{array}{l}\text { - } \quad \mathrm{As}_{5} \text { and } \mathrm{C}_{6} \text { sugars are exploited, } \\
\text { economics of process is strengthened } \\
\text { - Commercial yield of second } \\
\text { generation bioethanol increases }\end{array}$ & $\begin{array}{l}\text { - } \quad \text { Pretreatment step is required } \\
\text { Expense related with cellulase } \\
\text { enzymes are high }\end{array}$ \\
\hline
\end{tabular}


Table 4. Cont.

\begin{tabular}{|c|c|c|}
\hline $\begin{array}{c}\text { Process } \\
\text { Alternatives }\end{array}$ & Advantages & Disadvantage \\
\hline PSSF & $\begin{array}{l}\text { - Cost is low. A reactor can be used for } \\
\text { completing hydrolysis as well } \\
\text { as fermentation } \\
\text { Generate higher ethanol } \\
\text { concentration and (SHF), (SSF) have } \\
\text { less conversion rate than this process }\end{array}$ & $\begin{array}{l}\text { - } \quad \text { Time consuming process } \\
\text { - Costly cellulase enzymes needed for } \\
\text { enzymatic hydrolysis }\end{array}$ \\
\hline SSF & $\begin{array}{l}\text { - Cost is low. A reactor can be used for } \\
\text { completing hydrolysis as well } \\
\text { as fermentation } \\
\text { - } \quad \text { Ethanol yield is high } \\
\text { - Conversion time is less compared } \\
\text { to others }\end{array}$ & $\begin{array}{l}\text { - } \quad \text { Pretreatment step is required } \\
\text { - } \quad \text { follulase enzymes which are needed } \\
\text { - Fermentation process only } \\
\text { includes hexoses }\end{array}$ \\
\hline SSCF & $\begin{array}{l}\text { - } \quad \mathrm{As}_{5} \text { and } \mathrm{C}_{6} \text { sugars are exploited, } \\
\text { economics of process is strengthened } \\
\text { - } \quad \text { Commercial yield of second } \\
\text { generation bioethanol increases } \\
\text { - } \quad \text { Higher ethanol yield } \\
\text { - Shorter conversion time }\end{array}$ & $\begin{array}{l}\text { - } \quad \text { Pretreatment step is required } \\
\text { - } \quad \text { Costly cellulase enzymes needed } \\
\text { Microorganisms that are producing } \\
\text { high ethanol titles are not unavailable. }\end{array}$ \\
\hline
\end{tabular}

\subsection{Consolidate Bioprocessing by Fungi Species: A Viable Solution}

Some studies have been conducted to consolidate bioprocessing because of the benefits explained earlier. Several fungi are utilized to break down not only cellulose, but also the lignin, because of their high efficiency. Examples include ceriporia lacerate, mucor indicus, and pleurotus ostreatus [48,49]. On the other hand, many fungal species do not have the fermentative and enzymatic capability. For filamentous fungi, CBP, zygomycetes, as well as white-rot basidiomycetes are considered good choices [29]. These fungi have higher hyphal growth so that they can penetrate the substrate deeply as well as convert the lignocellulose substrates to bioethanol in a single step [29]. Table 5 summarizes the recent outlines of microorganisms implemented in CBP strategies when bioethanol is needed to be extracted from the potential lignocellulosic biomass materials.

Table 5. Recent outlines of microorganisms implemented in CBP strategies when bioethanol is needed to be extracted from the potential lignocellulosic biomass materials [29,48,50].

\begin{tabular}{clll}
\hline Microorganism & Lignocellulosic Biomass & $\begin{array}{c}\text { Ethanol } \\
\text { Concentration or } \\
\text { Yield }\end{array}$ & \multicolumn{1}{c}{ Comments } \\
\hline $\begin{array}{c}\text { Neurospora-crassa } \\
\text { (mesophilic } \\
\text { fungus) }\end{array}$ & Sorghum bagasse & $81.5 \%$ & $\begin{array}{l}\text { Solid-state cultivation is utilized } \\
\text { for enzyme generation }\end{array}$ \\
\hline $\begin{array}{c}\text { Phlebia radiata } \\
0043\end{array}$ & Core board & $\begin{array}{l}5.9 \mathrm{~g} / \mathrm{L}(10.4 \% \\
\text { ethanol yield })\end{array}$ & $\begin{array}{l}\text { bioethanol and organic acids, } \\
\text { oxalate and fumarate, are } \\
\text { produced }\end{array}$ \\
\hline $\begin{array}{c}\text { Fusarium } \\
\text { oxysporum }\end{array}$ & Cellulose 123 & $\begin{array}{l}0.044 \mathrm{~g} / \mathrm{L} / \mathrm{h} \text { and } \\
\text { a yield of } 0.35 \mathrm{~g} / \mathrm{g} \\
\text { cellulose }\end{array}$ & $\begin{array}{l}\text { Grows on cellulose when } \\
\text { aerobic conditions are ensured }\end{array}$ \\
\hline $\begin{array}{c}\text { Paecilomyces } \\
\text { variotii }\end{array}$ & Wheat bran & $1.2 \mathrm{~g} / \mathrm{L}$ of ethanol. & $\begin{array}{l}\text { Unusually powerful pentose } \\
\text { metabolic pathway. }\end{array}$ \\
\hline
\end{tabular}


Table 5. Cont.

\begin{tabular}{|c|c|c|c|}
\hline Microorganism & Lignocellulosic Biomass & $\begin{array}{c}\text { Ethanol } \\
\text { Concentration or } \\
\text { Yield }\end{array}$ & Comments \\
\hline $\begin{array}{l}\text { Peniophora } \\
\text { cinerea }\end{array}$ & $\begin{array}{l}\text { Glucose, mannose, } \\
\text { fructose, galactose, sucrose, } \\
\text { maltose and also cellobiose }\end{array}$ & $\begin{array}{l}0.41,0.45,0.44,0.19, \\
0.41,0.44 \text { and } 0.45 \mathrm{~g} \\
\text { per g hexose } \\
\text { respectively }\end{array}$ & $\begin{array}{l}\text { In PASC (amorphous cellulose), } \\
\text { P. cinerea was cultured and after } \\
18 \text { days it reached a maximum } \\
\text { ethanol yield of } 3 \mathrm{~g} / \mathrm{L}\end{array}$ \\
\hline $\begin{array}{l}\text { Trametes } \\
\text { suaveolens }\end{array}$ & $\begin{array}{l}\text { Glucose, mannose, } \\
\text { fructose, galactose, sucrose, } \\
\text { maltose and cellobiose }\end{array}$ & $\begin{array}{l}0.39,0.3,0.13,0.2, \\
0.37,0.35 \text { and } 0.31 \mathrm{~g} \\
\text { ethanol/g hexose }\end{array}$ & $\begin{array}{l}\text { Under both aerobic and } \\
\text { semiaerobic conditions, } 20 \mathrm{~g} / \mathrm{L} \text { of } \\
\text { carbon source should be used }\end{array}$ \\
\hline $\begin{array}{l}\text { Trametes } \\
\text { versicolor }\end{array}$ & Wheat bran and rice straw & $\begin{array}{l}5.0 \text { and } 4.8 \mathrm{~g} / \mathrm{L} \text {, } \\
\text { accordingly. } 92 \% \text { and } \\
91 \% \text { of the theoretical } \\
\text { yield. }\end{array}$ & $\begin{array}{l}\text { Favorable conversion to ethanol } \\
\text { is shown by Strain KT9427 }\end{array}$ \\
\hline Mucor indicus & $\begin{array}{l}\text { Lignocellulosic } \\
\text { hydrolysates }\end{array}$ & $\begin{array}{l}0.42-0.48 \mathrm{~g} / \mathrm{g} \\
\text { substrate }\end{array}$ & $\begin{array}{l}\text { It is evident from } \\
\text { the filamentous morphology of } \\
\text { M. indicts that highest yield of } \\
\text { ethanol can be achieved }\end{array}$ \\
\hline $\begin{array}{c}\text { Trichoderma } \\
\text { reesei A10 }\end{array}$ & Microcrystalline cellulose & $0.4 \mathrm{~g} / \mathrm{L}$ of ethanol & $\begin{array}{l}\text { Extracted from cow dung. } \\
\text { Under anaerobic conditions } \\
\text { shows no growth. }\end{array}$ \\
\hline
\end{tabular}

\section{The Scenario of Bioenergy Potential and Production in Bangladesh}

Day by day, usage of bioenergy for meeting ever-increasing energy demand is increasing globally. In 2014, bioenergy played an important role in global primary energy consumption with a share of approximately 10\%. The Renewable Global Status Report 2015 has predicted that by 2050 this number would increase to between 15\% and 50\% [51]. In Bangladesh, approximately 70\% of people directly or indirectly depend on biomass energy for daily household use, such as cooking or heating. Agriculture residues, municipal waste, and animal manure are the most familiar sources of biomass in Bangladesh, of which agricultural residues dominate biomass generation. Approximately $46 \%$ of the total bioenergy in Bangladesh originates from rice husk, rice straw, sugarcane bagasse, and jute sticks. Rice farms are the major users of agricultural land in Bangladesh, which produced approximately 58.503 million tonnes of agricultural residues during the fiscal year 2010-2011. More than one hundred rice mills are located around the country. Moreover, rice wasted from restaurants has also been used for biogas production. In Bangladesh, one project has produced $69 \%$ methane-enriched biogas using wasted rice $[52,53]$. Rice husk is obtained after paddy processing, which can be used to generate heat using the boilers to generate electricity. Approximately 9 million tonnes of rice husk was produced in 2011 [46]. The amount of surplus husk and the annual processing capacity was 455,366 tonnes and 3.62 million tonnes, respectively. Islam \& Ahiduzzaman (2013) estimated the electricity production from steam turbines and gasification plants using rice husk as a feedstock to be 41.45 and $29.05 \mathrm{MW}$, respectively [54].

The production of biofuels from biomass is being considered positively in Bangladesh. Renowned companies such as Nitol Motors are becoming increasingly interested in the production of biofuels from ethanol molasses [54]. Pongamia Pinnata and Jatropha Curcas are also promising biomass for biodiesel production in Bangladesh [55,56]. Biomass in the form of briquettes can also serve as a biofuel helping to mitigate various environmental challenges. Bangladesh has the potential to produce about one million tons of briquettes [57,58]. Sugarcane bagasse is also a good resource to be considered for green energy production, because Bangladesh has many sugar mills installed at various locations in the country [59]. Table 6 lists the total biomass potential of Bangladesh. 
Table 6. Biomass generation and energy production potential in Bangladesh [60].

\begin{tabular}{cccc}
\hline Source of Biomass & $\begin{array}{c}\text { Biomass Generation } \\
\text { (Million Tons) }\end{array}$ & Energy in PJ & $\begin{array}{c}\text { Electricity Generation } \\
\text { (TWh) }\end{array}$ \\
\hline Agricultural residues & 94.10 & 582.68 & 161.80 \\
Forest residues & 17.44 & 210.74 & 58.53 \\
Livestock residues & 88.89 & 456.65 & 126.81 \\
Municipal solid waste & 13.38 & 95.55 & 26.57 \\
Total & 213.81 & 1345.62 & 373.71 \\
\hline
\end{tabular}

\section{Methods and Data Source}

To determine the bioethanol production capability of Bangladesh, crop residues production and the properties first need to be investigated. To achieve this, annual crop production data were accumulated and multiplied by the FR (field residue) and PR (production residue). The generation of crop residue was then calculated and multiplied by the collectable coefficient to obtain the available crop residue. Finally, the available crop residue data were multiplied by the bioethanol conversion rate to obtain the bioethanol-potential data.

\subsection{Field Residue and Process Residue}

The collection of residue generally occurs during or after harvesting of the crops. Residues can be classified as FR or PR depending on the time of collection. FR is generally collected after harvesting and is used as fertilizer. The residue generated after crop processing is termed PR and is generally collected from mills where processing is done. In Bangladesh, residues from rice, maize, jute, and bagasse from sugarcane comprise approximately $46 \%$ of the total biomass production [52]. Some of these residues are used for cooking purposes as there is no natural gas supply available in the most of the rural areas of the country [61]. In this study, residues generated from crops in Bangladesh have been reviewed from surveying the literature [59] and presented in Table 7.

Table 7. Annual crop production in Bangladesh (2012-2013) and FR and PR index [55,59,60].

\begin{tabular}{ccccc}
\hline Crops & $\begin{array}{c}\text { Crop Production in Year } \\
\text { (ton) } \mathbf{( 2 0 1 2 - 2 0 1 3 )}\end{array}$ & Crops Residue & Total Residue \\
\hline & & $\begin{array}{c}\text { Field Residue } \\
\text { (FR) }\end{array}$ & $\begin{array}{c}\text { Process Residue } \\
(\text { PR) }\end{array}$ \\
Rice & $344.30 \times 10^{5}$ & 1.757 & 0.20 & FR + PR \\
Wheat & $10.36 \times 10^{5}$ & 1.70 & 0.30 & FR + PR \\
Maize & $20.42 \times 10^{5}$ & 2.00 & 0.30 & FR + PR \\
Sugarcane & $73.00 \times 10^{5}$ & 0.30 & 0.33 & FR + PR \\
Jute & $16.57 \times 10^{5}$ & 2.00 & NA & FR \\
Cotton & $0.28 \times 10^{5}$ & 3.52 & 0.47 & FR \\
Tobacco & $0.79 \times 10^{5}$ & 0.69 & NA & \\
\hline
\end{tabular}

\subsection{Utilization of Crop Residue}

In Bangladesh, biomass is the prime non-conventional fuel source, which is utilized for rustic cooking chores and domestic heating purposes. Bangladesh has abundant biomass resources. In addition, the abundant rainfall produces colossal biomass assets. These assets are considered a clean source that is composed of the following: residues produced from agriculture and forest, manure generated from animals, and MSW. Table 8 enlists the implementation design of the principal sources of biomass in Bangladesh. It is clear from the table that the majority of these sources are being used for cooking purposes. After that, they are used as a feedstock for animals, while wood is used only to make furniture. 
Table 8. The categories of utilization of agriculture residues in Bangladesh [59].

\begin{tabular}{|c|c|c|}
\hline Primary Source & Residue & Utilization \\
\hline Rice & Rice straw & $\begin{array}{l}\text { (i) Animal feed, (ii) animal bedding, (iii) housing } \\
\text { materials, and (iv) fuel }\end{array}$ \\
\hline Rice & Rice husk & (i) Poultry bedding, (ii) cattle feed, and (iii) fuel \\
\hline Wheat & Wheat straw & (i) Fuel and (ii) housing material \\
\hline Jute & Jute stalk & (i) Fuel and (ii) housing material \\
\hline Groundnut & Groundnut straw & (i) Fuel and (ii) animal feed \\
\hline Vegetable & Vegetable plants & (i) Fuel and (ii) animal feed \\
\hline Pulse & Pulse straw & (i) Fuel and (ii) animal feed \\
\hline \multirow[t]{2}{*}{ Sugarcane } & Sugarcane leafs & (i) Fuel and (ii) animal feed \\
\hline & Sugarcane bagasse & (i) Fuel \\
\hline \multirow[t]{2}{*}{ Maize } & Maize leafs & (i) Fuel and (ii) animal feed maize husk \\
\hline & Maize straw & (i) Fuel \\
\hline \multirow[t]{3}{*}{ Forest } & Leaves, twigs, and branches & (i) Fuel and (ii) fencing \\
\hline & Wood & (i) Furniture and (ii) fuel \\
\hline & Wood residue & (i) fuel \\
\hline
\end{tabular}

\subsection{Total Residue Available and Bioethanol Conversion Rate}

The amount of recoverable residue indicates the residue that can be taken from the field and utilized for processing to recover energy [62,63]. Previous studies [64-66] examined some of the central points associated with the recoverable crop residue, e.g., the height of crops, stubble height, and loss of residue during collection and storage processes. As indicated by these findings, Table 9 shows the determined collectable coefficient of residue and the theoretical bioethanol conversion rate of different crop residues. The calculation method for a hypothetical bioethanol transformation rate is based on the cellulose and hemicellulose substance found in various agricultural residues [63,67-71]. The available crop residue data multiplied by the bioethanol conversion rate provides the bioethanol-potential data.

Table 9. Theoretical bioethanol conversion rate of different crop residues [63].

\begin{tabular}{|c|c|c|}
\hline Residue & Collectable Coefficient & Conversion Rate $\left(\mathrm{g} \mathrm{kg}^{-1}\right)$ \\
\hline Rice & 0.79 & 521.09 \\
\hline Wheat & 0.70 & 487.75 \\
\hline Maize & 0.88 & 487.89 \\
\hline Bean & 0.54 & 363.51 \\
\hline Tubers & 0.76 & 561.20 \\
\hline Cotton & 0.88 & 442.65 \\
\hline Peanut & 0.83 & 342.54 \\
\hline Tobacco & 0.93 & 401.59 \\
\hline Sugarcane & 0.70 & 439.62 \\
\hline Canola (Rapeseed) & 0.65 & 460.20 \\
\hline Rape and Mustard & 0.84 & 492.19 \\
\hline Other oil crops & 0.85 & 492.19 \\
\hline Jute & 0.87 & 481.14 \\
\hline Other fibers & 0.86 & 481.14 \\
\hline
\end{tabular}

\section{Results and Discussions}

\subsection{Accessible Crop Residues}

In Bangladesh, the residues available from the seven major crops for bioethanol production were determined to be $65.36 \mathrm{Mt}$. Here, rice contributed the most with a value of almost $82 \%$ (Figure 2). The contributions from jute, maize, wheat, and sugarcane were found to be $4.40 \%, 6.31 \%, 2.21 \%$, and $4.22 \%$, respectively. From the period 2007 to 2016, the total residue available from all agriculture products for bioethanol production in China was reported to be 231.5 Mt [63]. Another study found 
that the annual dry biomass available for energy production in southern Italy was 1.493 tonne/ha [72]. In contrast, another study in Iran reported that the total pistachio waste available for bio-oil production was 1.73 tonne/ha [73].

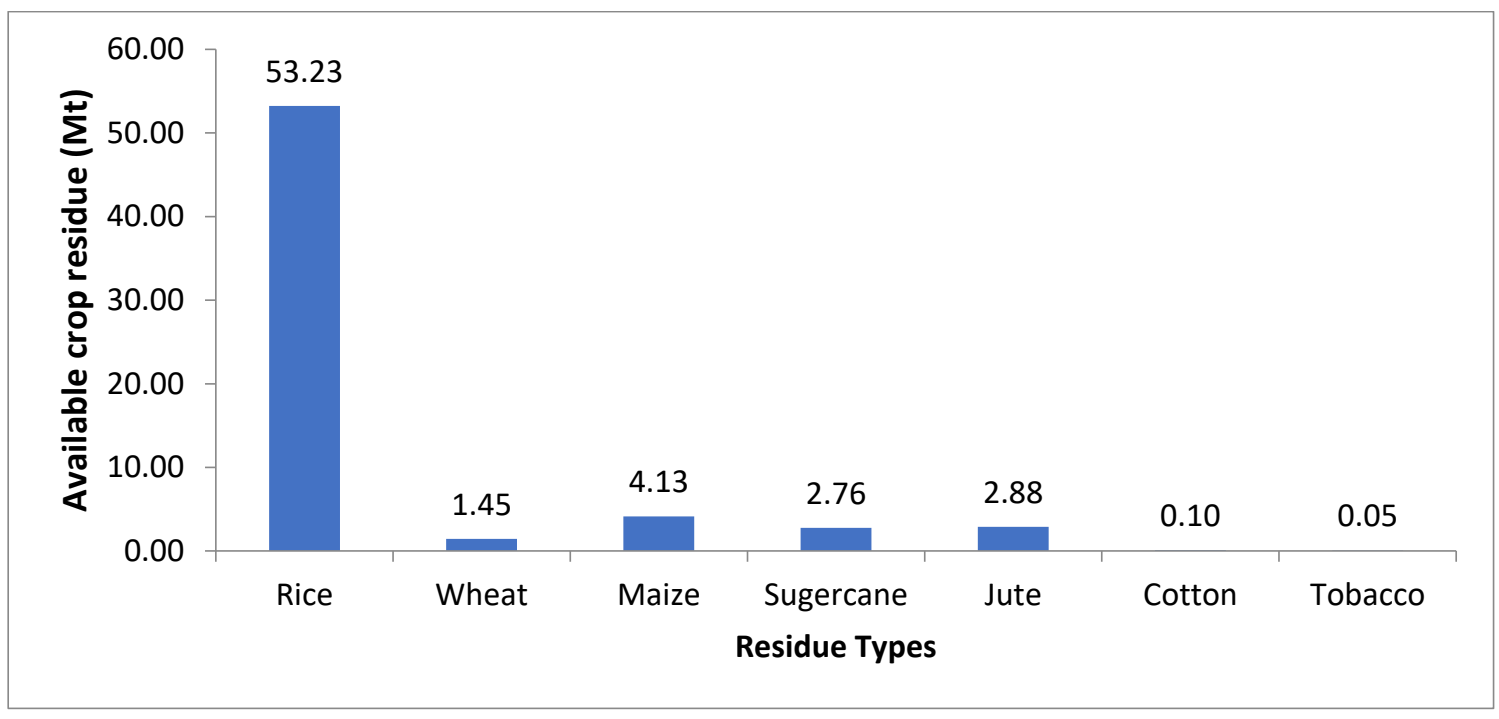

Figure 2. Available agricultural residue for bioethanol production in Bangladesh.

\subsection{Bioethanol Production}

Agricultural residues from seven major crops of Bangladesh have the potential to generate $32 \mathrm{Mt}$ of bioethanol with rice residues contributing up to $27.73 \mathrm{Mt}$ to the total bioethanol production (Figure 3). Sugarcane and jute contribute $4.3 \%$ and $4.24 \%$ to total bioethanol production, respectively. In Iran, 1.88 $\times 10^{-3} \mathrm{Mt}$ of bioethanol can be produced from $4.3 \times 10^{6} \mathrm{Mt}$ wheat wastes, whereas $1.13 \times 10^{-3} \mathrm{Mt}$ of bioethanol can be extracted from $1.05 \times 10^{6} \mathrm{Mt}$ of rice waste [74]. Similarly, in the U.S, $77.74 \times 10^{-3} \mathrm{Mt}$ of bioethanol was produced from $1.05 \times 10^{6} \mathrm{Mt}$ of wheat wastes [75]. In Bangladesh, if agricultural wastes are utilized properly, there will be a reduced need to import fuel from foreign countries. Rice husk is a major agricultural waste in Bangladesh. The bioethanol obtained from these residues can be used in vehicles in the transportation sector. E5, which is a blend of 5\% Ethanol and 95\% gasoline, can be used in transport vehicles effectively, as there is no need to do major modification in SI engine [19]. $137,000 \mathrm{Mt}$ of petrol, as well as 147,000 Mt of octane, were utilized as a fuel in the transportation sector in 2015-2016 [19]. This high usage of octane and petrol is a hindrance to the sustainable development of the country as well as the cause of major environmental hazards. Octane and petrol constitute about 90\% carbon by mass, and 3.3 tons of $\mathrm{CO}_{2}$ is produced from the combustion of 1 ton of petrol [19]. In contrast, bioethanol comprises of $52 \%$ carbon by mass, and 1.91 tons of $\mathrm{CO}_{2}$ is produced upon the combustion of 1 ton of bioethanol. It has been studied that if E5 is utilized in the transport sector, an annual 5\% reduction of $\mathrm{CO}_{2}$ can be possible in Bangladesh. If E5 is used in transport sector, it has been estimated that annual reduction in the consumption of petrol and octane in 2015-2016 will be 7 and 7.4 Kt. This will result in annual savings of 13 million USD. Bioethanol from agricultural residues can be used in this sector for better sustainability and reducing carbon emissions.

In Bangladesh, the agricultural sector has been significantly modernized, and as a result crop production has boomed. In 2017-2018, the total amount of crops generated was $657.6 \times 10^{5}$ tons [16]. From those crops, the amount of dry and wet agricultural residues obtained was 38.94 and 45.17 million tons, respectively. It has been estimated that from these agriculture residues, $618.37 \mathrm{PJ}$ of energy can be obtained, which is 5.77\% higher than in 2012-2013. Apart from livestock and MSW, $3.94 \%$ and $66.35 \%$ more energy can be recovered in 2017-2018 compared to 2012-2013. According to a study, to substitute $20 \%$ of the annual consumption of octane and fuel, 347,000 L of bioethanol is required per 
day. To produce this amount of bioethanol, 1.63 million metric tons of sugarcane, $250 \mathrm{kT}$ broken rice, and $340 \mathrm{kT}$ wheat are required [19].

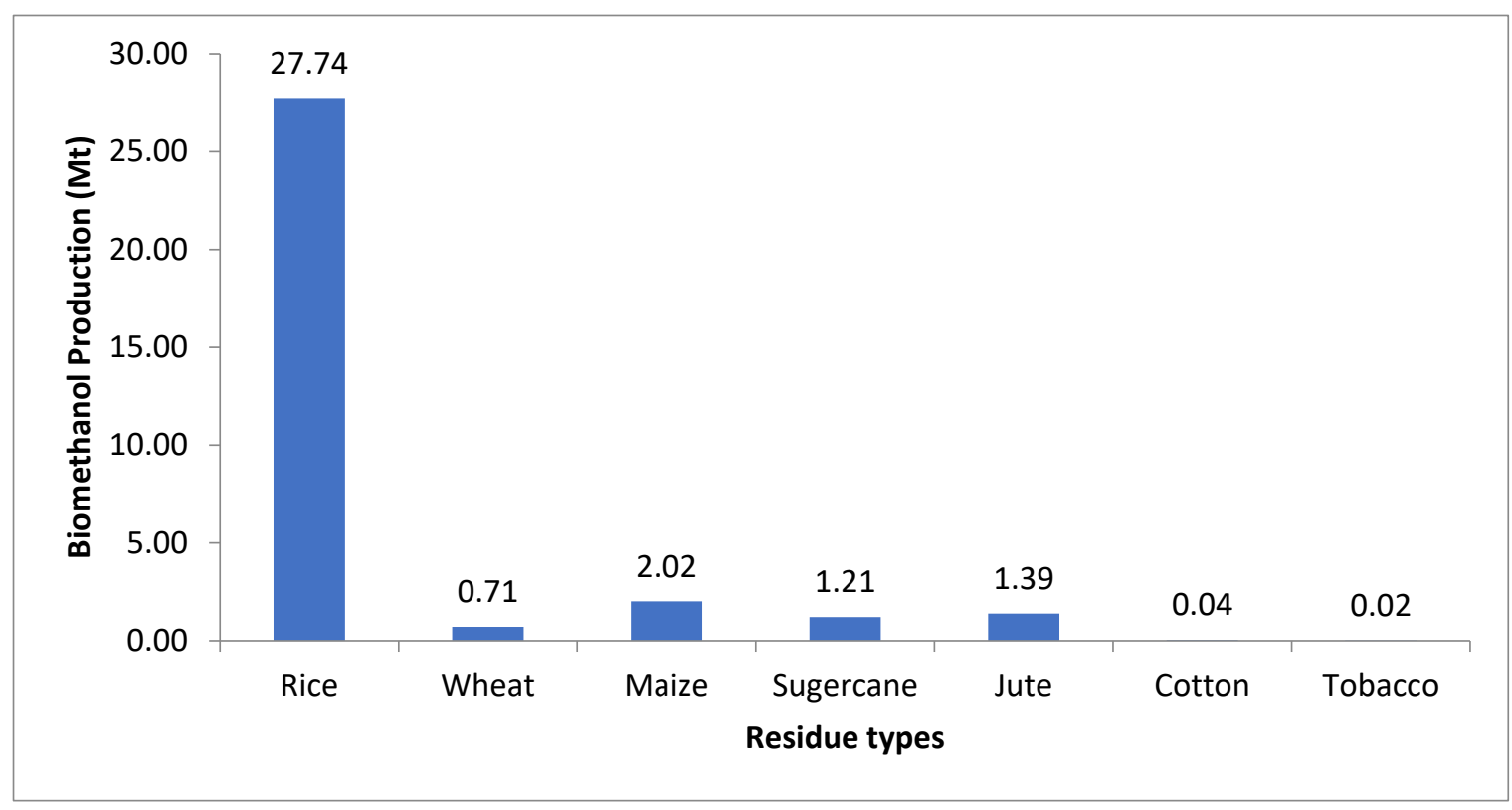

Figure 3. Bioethanol production capacity of agriculture residue in Bangladesh.

In Bangladesh, the above crops are likely to be grown in high quantities and carry a far lesser threat of running out than conventional fossil fuels. For example, in 2015, annual paddy production of Bangladesh was estimated to be 51.8 MMT. Assuming $8 \%$ of broken rice is produced during milling, the annual broken rice production in Bangladesh was around 4.2 MMT. Again, 1 ton of broken rice yields about 415 to 425 liters of bioethanol. To produce 114 million liters of bioethanol annually, around $250 \mathrm{kT}$ of broken rice would be needed per year. Currently, broken rice is used for making rice flour and poultry feed in our country. If broken rice is used as the principal raw material for the production of required bioethanol, about $6 \%$ of the total broken rice produced in Bangladesh will be required. Consuming $6 \%$ of broken rice to produce bioethanol is expected to have a very minimal effect on the food security of the country, hence providing a viable option to produce bioethanol.

\section{Significance of Biofuel Energy}

\subsection{Impact on Various Sectors in Bangladesh}

According to Agricultural Yearbook Statistics 2019, for rice production in the 2018-2019 fiscal year, Rangpur has the highest production with 6,458,898 metric tonnes, and Barishal has 2,264,915.5 metric tonnes of production, which is the lowest among others. Rangpur has the highest maize production of 1,945,214 metric tonnes, compared to other places of Bangladesh. As the rice husk is the major source of residue in the Bangladesh Rangpur region, it would contribute the most to bioethanol production. Sylhet has the lowest production considering all the major locations of Bangladesh for wheat, maize, sugarcane, jute, cotton, and tobacco production. After rice husk, maize, jute, and sugarcane contribute to the agricultural residue the most. The Rajshahi district of Bangladesh produces the highest sugarcane and wheat residue, as it has the highest sugarcane and wheat production of 1,417,810 metric tons and 403,614 metric tons, respectively. Dhaka contributes to the highest amount of Jute production as well as jute residue in Bangladesh. Regarding the cotton and tobacco production Khulna has the highest production of 17,370 metric tonnes and 49,592 metric tonnes, respectively [76]. Biomass to biofuel has a profound impact in generating sustainable power in Bangladesh. Burning of natural gas and bituminous coal produces approximately 1.93 and $2.46 \mathrm{~kg}$ of $\mathrm{CO}_{2}$ per $\mathrm{kg}$ of fuel [77]. Biofuels have 
lower $\mathrm{CO}_{2}$ emission rates than conventional fuels used in the power sectors of Bangladesh. Therefore, conversion of the biomass to biofuels can also be used to provide the necessary electricity supplies in Bangladesh. In the rural residential sector of Bangladesh, $90 \%$ of households use inefficient traditional biomass-based cooking devices, which contribute to higher energy destruction and less sustainability of the sector $[78,79]$. As a result, utilization of efficient biofuel in cooking can improve sustainability in the rural residential sector of Bangladesh.

\subsection{Future Studies}

Biofuels might be utilized as a substitute for diesel and gasoline, because the fossil fuels have a higher emission rate than biofuel [80-84]. Being a sustainable fuel, it can be employed in SI and $\mathrm{CI}$ engines, either in pure form or in the form of mixed blends with other fuels. Biofuels can be extracted from raw feedstock and agriculture waste. Animal fat and vegetable oil are good alternative sources of biodiesel production, and ethanol is extracted from the fermentation of crops, such as sugarcane. This method is usually implemented in the United States. In Brazil, fuel stations sell ethanol for transportation purposes [19]. The production of biofuel is attracting global attention because of the increased cost of oil from fossil fuels. A good amount of profits can be made from producing and selling the bioethanol, and $\mathrm{CO}_{2}$ emissions can be significantly reduced if ethanol is used in vehicles. A significant amount of petrol, as well as octane, is utilized as a fuel in the transportation sector in Bangladesh. Bioethanol from agriculture can be used in this sector for better sustainability and reducing carbon emissions. A detailed energy audit should be conducted to find out the most convenient energy efficacy measures that benefit local climates. Economic analysis, such as an exergo-economic analysis, should also be taken into consideration in future studies. The potential of various sustainable energy sources, for instance, solar, biogas, and biodiesel, should be investigated in the future. From the global perspective, as the world is facing climate-related challenges such as global warming, there will be changes in temperature, rainfall, and humidity. It is forecasted that by the end of 2020, 2050, and 2100, Bangladesh will experience an increase in annual temperature by $1{ }^{\circ} \mathrm{C}, 1.4{ }^{\circ} \mathrm{C}$, and $2.4{ }^{\circ} \mathrm{C}$, respectively $[85,86]$. This will definitely also change the agricultural crop residues production, as this crop production is contingent upon various factors including the aforementioned factors. However, within $2050,8 \%$ to $17 \%$ of the total rice production will decrease [85]. Future availability of agricultural residue in various locations of the country is dependent upon various crucial factors. As a result, whenever considering the future availability of the residues, further literature studies would be needed, as there are certain literature gaps present. The future studies with regards to the forecasting and model analysis can be done to predict the availability of various agricultural residues in the various regions of the country to utilize for the sustainable production of bioethanol for energy applications.

\section{Conclusions}

This paper reviewed the potential of agricultural residues for the production of bioethanol in Bangladesh. Proper utilization of these resources can lead to good profits in terms of reducing the import bills related to energy while improving the quality of environmental standards in the country. In Bangladesh, approximately $65.36 \mathrm{Mt}$ of agricultural residue is available from seven major crops from which it can be transformed to produce approximately $32 \mathrm{Mt}$ of bioethanol. Bioethanol from these residues can be used for transportation purposes, because it does not require any major modifications to the SI engine configuration when using E5. Though production cost is higher concerning Bangladesh, more work is needed to reduce this production cost for providing a sustainable future. The philosophy of utilizing sustainable resources is strongly recommended for Bangladesh, as it can reduce its need for fossil fuels. This study is based on the data available in different studies. Experimental on-site data based on the long term study can be collected as part of future research to assess the location-based bioethanol potential in Bangladesh. Moreover, based on the life cycle and techno-economic perspectives for the different regions of Bangladesh, the types of agricultural residues feasible for bioethanol production 
should also be explored via extensive research. Future research could also be focused on the emission characteristics of bioethanol utilization in Bangladesh.

Author Contributions: M.I.M. and T.C. developed the conceptualization and methodology of the study. H.C., A.A., and Y.-K.P. provided valuable research insights into the study, helped to review the manuscript, and helped with publishing. M.I.M. and P.C. provided literature resources and analysis, and S.M.S. contributed to the writing and provided valuable. All authors have read and agreed to the published the manuscript.

Funding: This research was supported by the National Research Foundation of Korea under the project 2019R1A4A1027795.

Acknowledgments: The authors would like to thank the Department of Mechanical Engineering, Chittagong University of Engineering and Technology, and the University of Seoul, Korea for providing support in preparing and publishing this manuscript.

Conflicts of Interest: The authors declare no conflict of interest.

\section{Nomenclature}

$\begin{array}{ll}\text { CI } & \text { Compression Ignition } \\ \text { FRI } & \text { Field Residue Index } \\ \text { PRI } & \text { Processing Residue Index } \\ \text { SI } & \text { Spark Ignition } \\ \text { E5 } & 5 \% \text { Ethanol mixed with } 95 \% \text { gasoline } \\ \text { HHV } & \text { Higher heating value } \\ \text { Mt } & \text { Mega tonnes } \\ \text { MSW } & \text { Municipal solid waste } \\ \text { ARP } & \text { Ammonia recycling percolation } \\ \text { AFE } & \text { Ammonia fiber explosion } \\ \text { EH } & \text { Enzymatic hydrolysis } \\ \text { SSF } & \text { Simultaneous saccharification and fermentation } \\ \text { SSCF } & \text { Simultaneous saccharification and co-fermentation } \\ \text { CBP } & \text { Consolidated bioprocessing } \\ \text { SHCF } & \text { Separate hydrolysis and co-fermentation } \\ \text { FB } & \text { Fermentation of biomass } \\ \text { BY } & \text { Bioethanol yield }\end{array}$

\section{References}

1. Jamil, F.; Aslam, M.; Al-Muhtaseb, A.H.; Bokhari, A.; Rafiq, S.; Khan, Z.; Inayat, A.; Ahmed, A.; Hossain, S.; Khurrum, M.S.; et al. Greener and sustainable production of bioethylene from bioethanol: Current status, opportunities and perspectives. Rev. Chem. Eng. 2020, 1, 36.

2. Ahmed, A.; Abu Bakar, M.S.; Azad, A.K.; Sukri, R.S.; Mahlia, T.M.I. Potential thermochemical conversion of bioenergy from Acacia species in Brunei Darussalam: A review. Renew. Sustain. Energy Rev. 2017, 82, 3060-3076. [CrossRef]

3. Chowdhury, T.; Chowdhury, H.; Ahmed, A.; Park, Y.K.; Chowdhury, P.; Hossain, N.; Sait, S.M. Energy, exergy, and sustainability analyses of the agricultural sector in Bangladesh. Sustainability 2020, 12, 4447. [CrossRef]

4. Moogi, S.; Nakka, L.; Potharaju, S.S.P.; Ahmed, A.; Farooq, A.; Jung, S.C.; Rhee, G.H.; Park, Y.K. Copper promoted $\mathrm{Co} / \mathrm{MgO}$ : A stable and efficient catalyst for glycerol steam reforming. Int. J. Hydrog. Energy 2020. [CrossRef]

5. Abu Bakar, M.S.; Ahmed, A.; Jeffery, D.M.; Hidayat, S.; Sukri, R.S.; Mahlia, T.M.I.; Jamil, F.; Khurrum, M.S.; Inayat, A.; Moogi, S.; et al. Pyrolysis of solid waste residues from Lemon Myrtle essential oils extraction for bio-oil production. Bioresour. Technol. 2020, 1-5. [CrossRef]

6. Liu, S.; Abrahamson, L.P.; Scott, G.M. Biorefinery: Ensuring biomass as a sustainable renewable source of chemicals, materials, and energy. Biomass Bioenergy 2012, 39, 1-4. [CrossRef]

7. Ashraful, A.M.; Masjuki, H.H.; Kalam, M.A.; Rizwanul Fattah, I.M.; Imtenan, S.; Shahir, S.A.; Mobarak, H.M. Production and comparison of fuel properties, engine performance, and emission characteristics of biodiesel from various non-edible vegetable oils: A review. Energy Convers. Manag. 2014, 80, 202-228. [CrossRef] 
8. Moogi, S.; Jae, J.; Kannapu, H.P.R.; Ahmed, A.; Park, E.D.; Park, Y. Enhancement of aromatics from catalytic pyrolysis of yellow poplar: Role of hydrogen and methane decomposition. Bioresour. Technol. 2020, 123835. [CrossRef]

9. Behera, S.S.; Ray, R.C. Forest Bioresources for Bioethanol and Biodiesel production with Emphasis on Mohua (Madhuca latifolia L.) Flowers and Seeds. In Bioethanol Production from Food Crops; Elsevier: Amsterdam, The Netherlands, 2019; pp. 233-247. ISBN 9780128137666.

10. Swain, M.R.; Mohanty, S.K. Bioethanol Production from Corn and Wheat: Food, Fuel, and Future. In Bioethanol Production from Food Crops; Elsevier: Amsterdam, The Netherlands, 2019; pp. 45-59. ISBN 9780128137666.

11. Solange, M.; José, T. Lignocellulose as Raw Material in Fermentation Processes. In Current Research, Technology and Education Topics in Applied Microbiology and Microbial Biotechnology; Méndez-Vilas, A., Ed.; Formatex Research Center: Badajoz, Spain, 2010; pp. 897-907.

12. Biomass Energy Foundation. Proximate/Ultimate Analysis. Available online: http://drtlud.com/BEF/ proximat.htm (accessed on 3 April 2020).

13. Grover, S.; Kathuria, R.S.; Kaur, M. Energy values and technologies for non woody biomass: As a clean source of energy. IOSR J. Electr. Electron. Eng. 2012, 1, 10-14. [CrossRef]

14. Khuong, L.S.; Zulkifli, N.W.M.; Masjuki, H.H.; Mohamad, E.N.; Arslan, A.; Mosarof, M.H.; Azham, A. A review on the effect of bioethanol dilution on the properties and performance of automotive lubricants in gasoline engines. RSC Adv. 2016, 6, 66847-66869. [CrossRef]

15. Mosaddek Hossen, M.; Sazedur Rahman, A.H.M.; Kabir, A.S.; Faruque Hasan, M.M.; Ahmed, S. Systematic assessment of the availability and utilization potential of biomass in Bangladesh. Renew. Sustain. Energy Rev. 2017, 67, 94-105. [CrossRef]

16. Uddin, M.N.; Taweekun, J.; Techato, K.; Rahman, M.A.; Mofijur, M.; Rasul, M.G. Sustainable Biomass as an Alternative Energy Source: Bangladesh Perspective. Energy Procedia 2019, 160, 648-654. [CrossRef]

17. Salam, M.A.; Ahmed, K.; Akter, N.; Hossain, T.; Abdullah, B. A review of hydrogen production via biomass gasification and its prospect in Bangladesh. Int. J. Hydrog. Energy 2018, 43, 14944-14973. [CrossRef]

18. Household Different Biomass Resources Consumption throughout Bangladesh. 2018. Available online: https://www.statista.com/statistics/281606/ethanol-production-in-selected-countries (accessed on 17 March 2020).

19. Hossain, S.F.; Bint-E-Naser, M.S.; Khan, A. Case Study: A Review on Prospects and Constraints of Bioethanol Production in Bangladesh. In Biofuels: Advances \& Perspectives; Kaushik, G., Chaturvedi, S., Chel, A., Eds.; Studium Press LLC: New Delhi, India, 2017; pp. 69-86. ISBN 978-93-85046-22-3.

20. Parisutham, V.; Kim, T.H.; Lee, S.K. Feasibilities of consolidated bioprocessing microbes: From pretreatment to biofuel production. Bioresour. Technol. 2014, 161, 431-440. [CrossRef] [PubMed]

21. Gil, N.; Ferreira, S.; Amaral, M.E.; Domingues, F.C.; Duarte, A.P. The influence of dilute acid pretreatment conditions on the enzymatic saccharification of Erica spp. for bioethanol production. Ind. Crops Prod. 2010, 32, 29-35. [CrossRef]

22. Axelsson, L.; Franzén, M.; Ostwald, M.; Berndes, G.; Lakshmi, G.; Ravindranath, N.H. Perspective: Jatropha cultivation in southern India: Assessing farmers' experiences. Biofuels Bioprod. Biorefin. 2012, 6, 246-256. [CrossRef]

23. Romero-García, J.M.; Niño, L.; Martínez-Patiño, C.; Álvarez, C.; Castro, E.; Negro, M.J. Biorefinery based on olive biomass. State of the art and future trends. Bioresour. Technol. 2014, 159, 421-432. [CrossRef] [PubMed]

24. Ibrahim, M.F.; Ramli, N.; Kamal Bahrin, E.; Abd-Aziz, S. Cellulosic biobutanol by Clostridia: Challenges and improvements. Renew. Sustain. Energy Rev. 2017, 79, 1241-1254. [CrossRef]

25. Zabed, H.; Sahu, J.N.; Boyce, A.N.; Faruq, G. Fuel ethanol production from lignocellulosic biomass: An overview on feedstocks and technological approaches. Renew. Sustain. Energy Rev. 2016, 66, 751-774. [CrossRef]

26. Cardona, C.A.; Quintero, J.A.; Paz, I.C. Production of bioethanol from sugarcane bagasse: Status and perspectives. Bioresour. Technol. 2010, 101, 4754-4766. [CrossRef]

27. Isroi; Millati, R.; Syamsiah, S.; Niklasson, C.; Cahyanto, M.N.; Lundquist, K.; Taherzadeh, M.J. Biological pretreatment of lignocelluloses with white-rot fungi and its applications: A review. BioResources 2011, 6, 5224-5259. [CrossRef] 
28. Najafi, G.; Ghobadian, B.; Tavakoli, T.; Yusaf, T. Potential of bioethanol production from agricultural wastes in Iran. Renew. Sustain. Energy Rev. 2009, 13, 1418-1427. [CrossRef]

29. Carrillo-Nieves, D.; Rostro Alanís, M.J.; de la Cruz Quiroz, R.; Ruiz, H.A.; Iqbal, H.M.N.; Parra-Saldívar, R. Current status and future trends of bioethanol production from agro-industrial wastes in Mexico. Renew. Sustain. Energy Rev. 2019, 102, 63-74. [CrossRef]

30. Paulova, L.; Patakova, P.; Branska, B.; Rychtera, M.; Melzoch, K. Lignocellulosic ethanol: Technology design and its impact on process efficiency. Biotechnol. Adv. 2015, 33, 1091-1107. [CrossRef]

31. Kaida, R.; Kaku, T.; Baba, K.; Oyadomari, M.; Watanabe, T.; Hartati, S.; Sudarmonowati, E.; Hayashi, T. Enzymatic saccharification and ethanol production of Acacia mangium and Paraserianthes falcataria wood, and Elaeis guineensis trunk. J. Wood Sci. 2009, 55, 381-386. [CrossRef]

32. Bilal, M.; Nawaz, M.Z.; Iqbal, H.M.N.; Hou, J.; Mahboob, S.; Al-Ghanim, K.A.; Hairong, C. Engineering ligninolytic consortium for bioconversion of lignocelluloses to ethanol and chemicals. Protein Pept. Lett. 2018, 25. [CrossRef] [PubMed]

33. Barkalow, D.G.; Whistler, R.L. Cellulose, AccessScience. 2008. Available online: http://www.accessscience. com (accessed on 30 March 2020).

34. Mesa, L.; González, E.; Romero, I.; Ruiz, E.; Cara, C.; Castro, E. Comparison of process configurations for ethanol production from two-step pretreated sugarcane bagasse. Chem. Eng. J. 2011, 175, 185-191. [CrossRef]

35. Olofsson, K.; Bertilsson, M.; Lidén, G. A short review on SSF - An interesting process option for ethanol production from lignocellulosic feedstocks. Biotechnol. Biofuels 2008, 1, 1-14. [CrossRef]

36. Chiaramonti, D.; Rizzo, A.M.; Prussi, M.; Tedeschi, S.; Zimbardi, F.; Braccio, G.; Viola, E.; Pardelli, P.T. 2nd generation lignocellulosic bioethanol: Is torrefaction a possible approach to biomass pretreatment? Biomass Convers. Biorefin. 2011, 1, 9-15. [CrossRef]

37. Rastogi, M.; Shrivastava, S. Recent advances in second generation bioethanol production: An insight to pretreatment, saccharification and fermentation processes. Renew. Sustain. Energy Rev. 2017, 80, 330-340. [CrossRef]

38. Kim, T.H.; Taylor, F.; Hicks, K.B. Bioethanol production from barley hull using SAA (soaking in aqueous ammonia) pretreatment. Bioresour. Technol. 2008, 99, 5694-5702. [CrossRef] [PubMed]

39. Morales-Rodriguez, R.; Gernaey, K.V.; Meyer, A.S.; Sin, G. A Mathematical model for simultaneous saccharification and co-fermentation (SSCF) of C6 and C5 sugars. Chin. J. Chem. Eng. 2011, 19, 185-191. [CrossRef]

40. Taherzadeh, M.J.; Karimi, K. Acid-based hydrolysis processes for ethanol from lignocellulosic materials: A review. Bioresources 2007, 125, 127-134. [CrossRef]

41. Amore, A.; Faraco, V. Potential of fungi as category i Consolidated BioProcessing organisms for cellulosic ethanol production. Renew. Sustain. Energy Rev. 2012, 16, 3286-3301. [CrossRef]

42. Amoah, J.; Ishizue, N.; Ishizaki, M.; Yasuda, M.; Takahashi, K.; Ninomiya, K.; Yamada, R.; Kondo, A.; Ogino, C. Development and evaluation of consolidated bioprocessing yeast for ethanol production from ionic liquid-pretreated bagasse. Bioresour. Technol. 2017, 245, 1413-1420. [CrossRef]

43. Brethauer, S.; Studer, M.H. Consolidated bioprocessing of lignocellulose by a microbial consortium. Energy Environ. Sci. 2014, 7, 1446-1453. [CrossRef]

44. Okamoto, K.; Uchii, A.; Kanawaku, R.; Yanase, H. Bioconversion of xylose, hexoses and biomass to ethanol by a new isolate of the white rot basidiomycete Trametes versicolor. Springerplus 2014, 3, 1-9. [CrossRef]

45. Mattila, H.; Kuuskeri, J.; Lundell, T. Single-step, single-organism bioethanol production and bioconversion of lignocellulose waste materials by phlebioid fungal species. Bioresour. Technol. 2017, 225, 254-261. [CrossRef]

46. Food and Agriculture Organization of United Nations. Available online: http://faostat.fao.org/site/339/default (accessed on 5 March 2020).

47. Chovau, S.; Degrauwe, D.; Van Der Bruggen, B. Critical analysis of techno-economic estimates for the production cost of lignocellulosic bio-ethanol. Renew. Sustain. Energy Rev. 2013, 26, 307-321. [CrossRef]

48. Kaneko, S.; Mizuno, R.; Maehara, T.; Ichinose, H. Consolidated Bioprocessing Ethanol Production by Using a Mushroom. In Bioethanol; Intech: Rijeka, Croatia, 2012. [CrossRef]

49. Uçkun Kiran, E.; Trzcinski, A.P.; Ng, W.J.; Liu, Y. Bioconversion of food waste to energy: A review. Fuel 2014, 134, 389-399. [CrossRef] 
50. Lee, D.Y.; Ebie, Y.; Xu, K.Q.; Li, Y.Y.; Inamori, Y. Continuous H2 and CH4 production from high-solid food waste in the two-stage thermophilic fermentation process with the recirculation of digester sludge. Bioresour. Technol. 2010, 101, S42-S47. [CrossRef] [PubMed]

51. Renewables 2015 Global Status Report. Available online: http://www.ren21.net/wp-content/uploads/2015/07/ REN12-GSR2015_Onlinebook_low1.pdf (accessed on 5 May 2020).

52. Rofiqul Islam, M.; Rabiul Islam, M.; Rafiqul Alam Beg, M. Renewable energy resources and technologies practice in Bangladesh. Renew. Sustain. Energy Rev. 2008, 12, 299-343. [CrossRef]

53. Baky, M.A.H.; Hassan Khan, M.N.; Kader, M.F.; Chowdhury, H.A. Production of Biogas by Anaerobic Digestion of Food Waste and Process Simulation. In Proceedings of the ASME 2014 8th International Conference on Energy Sustainability collocated with the ASME 2014 12th International Conference on Fuel Cell Science, Engineering and Technology, Boston, MA, USA, 30 June 2014.

54. Islam, A.; Chan, E.S.; Taufiq-Yap, Y.H.; Mondal, M.A.H.; Moniruzzaman, M.; Mridha, M. Energy security in Bangladesh perspective-An assessment and implication. Renew. Sustain. Energy Rev. 2014, 32, $154-171$. [CrossRef]

55. Halder, P.K.; Paul, N.; Beg, M.R.A. Prospect of Pongamia pinnata (Karanja) in Bangladesh: A Sustainable Source of Liquid Fuel. J. Renew. Energy 2014, 2014, 1-12. [CrossRef]

56. Nabi, M.N.; Hoque, S.M.N.; Akhter, M.S. Karanja (Pongamia Pinnata) biodiesel production in Bangladesh, characterization of karanja biodiesel and its effect on diesel emissions. Fuel Process. Technol. 2009, 90, 1080-1086. [CrossRef]

57. Ahiduzzaman, M.; Islam, A.K.M.S. Greenhouse gas emission and renewable energy sources for sustainable development in Bangladesh. Renew. Sustain. Energy Rev. 2011, 15, 4659-4666. [CrossRef]

58. Ahiduzzaman, M. Sustainability of biomass energy development technology (densification) in Bangladesh. Int. J. Bio. Res. 2006, 1, 40-46.

59. Huda, A.S.N.; Mekhilef, S.; Ahsan, A. Biomass energy in Bangladesh: Current status and prospects. Renew. Sustain. Energy Rev. 2014, 30, 504-517. [CrossRef]

60. Halder, P.K.; Paul, N.; Beg, M.R.A. Assessment of biomass energy resources and related technologies practice in Bangladesh. Renew. Sustain. Energy Rev. 2014, 39, 444-460. [CrossRef]

61. Mamun, M.R.A.; Kabir, M.S.; Alam, M.M.; Islam, M.M. Utilization pattern of biomass for rural energy supply in Bangladesh. Int. J. Sustain. Crop Prod. 2009, 4, 62-71.

62. Wang, Y.J.; Bi, Y.Y.; Gao, C.Y. The Assessment and Utilization of Straw Resources in China. Agric. Sci. China 2010, 9, 1807-1815. [CrossRef]

63. Fang, Y.R.; Wu, Y.; Xie, G.H. Crop residue utilizations and potential for bioethanol production in China. Renew. Sustain. Energy Rev. 2019, 113. [CrossRef]

64. Ren, J.; Yu, P.; Xu, X. Straw utilization in China-status and recommendations. Sustainability 2019, 11, 1762. [CrossRef]

65. Zhichen, L.; Xuantong, Z. Energy utilization potential of wheat straw in an ecological balance-a case study of henan province in China. Resources 2019, 8, 41. [CrossRef]

66. He, K.; Zhang, J.; Zeng, Y.; Zhang, L. Households' willingness to accept compensation for agricultural waste recycling: Taking biogas production from livestock manure waste in Hubei, P.R. China as an example. J. Clean. Prod. 2016, 131, 410-420. [CrossRef]

67. Garivait, S.; Chaiyo, U.; Patumsawad, S.; Deakhuntod, J. Physical and chemical properties of thai biomass fuels from agricultural residues. In Proceedings of the 2nd Joint International Conference on Sustainable Energy and Environment, Bangkok, Thailand, 21-23 November 2006; pp. 1-23.

68. Szymanska-Chargot, M.; Chylinska, M.; Gdula, K.; Koziol, A.; Zdunek, A. Isolation and characterization of cellulose from different fruit and vegetable pomaces. Polymers 2017, 9, 495. [CrossRef]

69. Jiang, D.; Zhuang, D.; Fu, J.; Huang, Y.; Wen, K. Bioenergy potential from crop residues in China: Availability and distribution. Renew. Sustain. Energy Rev. 2012, 16, 1377-1382. [CrossRef]

70. Seglah, P.A.; Wang, Y.; Wang, H.; Bi, Y. Estimation and efficient utilization of straw resources in Ghana. Sustainability 2019, 11, 4172. [CrossRef]

71. Teixeira Franco, R.; Buffière, P.; Bayard, R. Ensiling for biogas production: Critical parameters. A review. Biomass Bioenergy 2016, 94, 94-104. [CrossRef]

72. Algieri, A.; Andiloro, S.; Tamburino, V.; Zema, D.A. The potential of agricultural residues for energy production in Calabria (Southern Italy). Renew. Sustain. Energy Rev. 2019, 104, 1-14. [CrossRef] 
73. Mehralian, M.; Chegini, Z.G.; Khashij, M. Activated carbon prepared from pistachio waste for dye adsorption: Experimental and CCD-based design. Pigment Resin Technol. 2019, 49, 136-144. [CrossRef]

74. Taghizadeh-Alisaraei, A.; Assar, H.A.; Ghobadian, B.; Motevali, A. Potential of biofuel production from pistachio waste in Iran. Renew. Sustain. Energy Rev. 2017, 72, 510-522. [CrossRef]

75. Kim, S.; Dale, B.E. Global potential bioethanol production from wasted crops and crop residues. Biomass Bioenergy 2004, 26, 361-375. [CrossRef]

76. Bangladesh Bureau of Statisctics (BBS). Yearbook of Agricultural Statistics of Bangladesh; BBS: Dhaka, Bangladesh, 2020.

77. Carbon Emissions from Burning Biomass Energy. Available online: http://www.pfpi.net/wp-content/uploads/ 2011/04/PFPI-biomass-carbon-accounting-overview_April.pdf (accessed on 4 October 2020).

78. Chowdhury, H.; Chowdhury, T.; Chowdhury, P.; Islam, M.; Saidur, R.; Sait, S.M. Integrating sustainability analysis with sectoral exergy analysis: A case study of rural residential sector of Bangladesh. Energy Build. 2019, 202, 109397. [CrossRef]

79. Banu, L.B. Technologies for efficient use of wood fuel: Improved chulli, compressed husk, briquetting and other technologies. In National Training Course on Wood Fuel in Bangladesh_Production and Marketing; FAO: Bogra, Bangladesh, 1996.

80. Ahmed, A.; Abu Bakar, M.S.; Hamdani, R.; Park, Y.K.; Lam, S.S.; Sukri, R.S.; Hussain, M.; Majeed, K.; Phusunti, N.; Jamil, F.; et al. Valorization of underutilized waste biomass from invasive species to produce biochar for energy and other value-added applications. Environ. Res. 2020, 186, 109596. [CrossRef]

81. Reza, S.; Ahmed, A.; Caesarendra, W.; Bakar, M.S.A.; Shams, S.; Saidur, R.; Aslfattahi, N.; Azad, A.K. Acacia Holosericea: An Invasive Species for Bio-char, Bio-oil, and Biogas Production. Bioengineering 2019, 6, 33. [CrossRef]

82. Radenahmad, N.; Morni, N.A.; Ahmed, A.; Abu Bakar, M.; Zaini, J.; Azad, A. Characterization of rice husk as a potential renewable energy source. In Proceedings of the 7th Brunei InternationalL Conference on Engineering and Technology (BICET 2018), Bandar Seri Begawan, Brunei, 12-14 November 2018; pp. 1-4.

83. Abdullah, A.; Ahmed, A.; Akhter, P.; Razzaq, A.; Zafar, M.; Hussain, M.; Shahzad, N.; Majeed, K.; Khurrum, S.; Saifullah, M.; et al. Bioenergy potential and thermochemical characterization of lignocellulosic biomass residues available in Pakistan. Korean Inst. Chem. Eng. 2020, 37, 1-8. [CrossRef]

84. Chowdhury, T.; Chowdhury, H.; Hossain, N.; Ahmed, A.; Hossen, M.S.; Chowdhury, P.; Thirugnanasambandam, M.; Saidur, R. Latest Advancements on Livestock Waste Management and Biogas Production: Bangladesh's perspective. J. Clean. Prod. 2020, 272. [CrossRef]

85. Ahmed, A.U. Bangladesh Climate Change Impacts and Vulnerability: A Synthesis; Climate Change Cell, Department of Environment, CDMP, Government of the People's Republic of Bangladesh: Dhaka, Bangladesh, 2006.

86. Sarker, M.A.R.; Alam, K.; Gow, J. Exploring the Relationship between Climate Change and Rice Yield in Bangladesh: An Analysis of Time Series Data. Agric. Syst. 2012, 112, 11-16. [CrossRef]

Publisher's Note: MDPI stays neutral with regard to jurisdictional claims in published maps and institutional affiliations.

(C) 2020 by the authors. Licensee MDPI, Basel, Switzerland. This article is an open access article distributed under the terms and conditions of the Creative Commons Attribution (CC BY) license (http://creativecommons.org/licenses/by/4.0/). 